\title{
アイソタクチックポリオクタデセン-1 の粘弾性と結晶転移*1
}

（昭 和 45 年 1 月 31 日 受 理）

\author{
真 鍋 征 一*2・高柳 素夫*3
}

アイソタクチックポリオクタデセン-1 の粘弾性温度特性においては $-145^{\circ} \mathrm{C}$ 付近 $(110 \mathrm{~Hz})$ 飞側鎖自身の局所的ねじれ運動 による吸収, および $-40^{\circ} \mathrm{C} \sim 30^{\circ} \mathrm{C}$ の温度範囲に少くとも 4 つの吸収が見いだされる。高温より $\alpha_{\mathrm{c}}{ }^{\prime}, \alpha_{\mathrm{c}}{ }^{\prime \prime}, \alpha_{\mathrm{a}}{ }^{\prime}, \alpha_{\mathrm{a}}{ }^{\prime \prime}$ と名づけ, $\alpha_{\mathrm{c}}{ }^{\prime}$ と $\alpha_{\mathrm{c}}{ }^{\prime \prime}$ は結晶領域内の分子鎖運動によるもので, $\alpha_{\mathrm{a}}{ }^{\prime \prime}$ は無定形領域, $\alpha_{\mathrm{a}}{ }^{\prime}$ はそれに近い非結晶領域の分子鎖運動によるもの と考えられる。

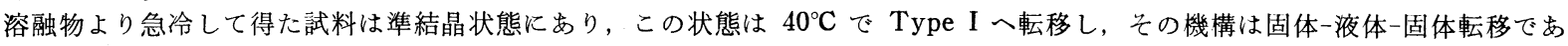
る。すなわちまず側鎖が Type I の規則性を持ち，その後に主鎖が規則性を持つ。Type I は $63^{\circ} \mathrm{C}$ 付近から徐々に Type II 変化し, この変化は Type I の顕著な融解を伴なわずに起こり，主鎖と側鎖は同時に Type II の規則性を持つ。 $20 \sim 75^{\circ} \mathrm{C}$ の温 度範囲で Type II 結晶が上記 3 者の結晶型の中で最も熱力学的に安定である。

\section{1 緒言}

Turner-Jones ${ }^{1)}$ により, アイソタクチックポリオクタデセ ン-1（略号 POD）の結晶構造が詳しく検討された。それによる と大きくわけて 3 種の結晶型が存在し, それを Type II, Type I, partially ordered form (pof) と名付けている。 Type II と Type I 結晶は側鎖のみならず主鎖も結晶格子内に入っており， pof は主として側鎖のみが結晶していると考えられている。これ ら結晶の側鎖の充てん状態はポリエチレン $(\mathrm{PE})$ 結晶中の主鎖と 同種の充てん状態にある。すなわち側鎖が PE 結晶を作るように 充てんする。Type II 結晶に抢いては主鎖は 3 回または 4 回のラ センを巻いており，側鎖はこのラセン軸に対して $49.4^{\circ}$ の角度 で伸びきっている。Type I 結晶では側鎖は主鎖（おそらくはラ センを巻いているであろう) の軸に対して直角方向に伸びきって いる。そのため主鎖一主鎖間の間隔は Type I 結晶の方が大きい。 また pof の特徴はX線的には $4.2 \AA$ に強い反射を与えるのみで 主鎖からの反射は見られない。従って側鎖のみが部分的に六方晶 的に結晶したものと考光られ，主鎖は結晶していない。しかし， これら結晶型の転移機洅およびその粘弾性挙動については現在ま で研究例 2,3$)$ はごく少ない。本報告は粘弾性挙動におよぼす化学 構造の影響をしる目的で, 長い側鎖を持つポリー $\alpha$-オレフィン系 列の粘弾性挙動をとりあげその研究の一環としての表記ポリマー について検討した結果である。POD は主鎖炭素数 2 に対し側鎖 炭素数 16 で側鎖自身の運動性が粘弾性挙動に顕著に反映される ことが期待される。

\section{2 実験}

$2 \cdot 1$ 試 料

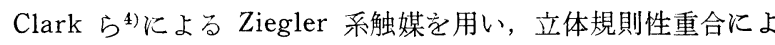

*1 この報文を「分岐のない側鎖を持つポリー $\alpha$-オレフィン系 列の粘弾性と結晶転移現象（第1 報)」とする.

*2 Seiichi MANABE 現在旭化成繊維研究所：高梘市八丁畷 町.

*3 Motowo TAKAYANAGI 九州大学工学部応用化学教室 : 福岡市箱崎.

1) A. Turner-Jones, Makromol. Chem., 75, 1 (1964).

2) S. Manabe, H. Nakamura, S. Uemura, M. Takayanagi, Rep. Prog. Polymer. Phys. Japan, 9, 349 (1966).

3) D. W. Aubrey, A. Barnatt, J. Polym. Sci., (Part A-2), 6. 241 (1968).
って得たポリマーを，メタノールついでェチルェーテルでそれぞ れ 8 時間以上抽出を行ない, 不溶分をアイソタクチック成分とし て用いた。試料の同定はX線回折図形の解析により,さらに文献 值 ${ }^{1,4)}$ との比較により行なった。

溶液からの結晶化の方法は, テトラヒドロフランを溶媒として $0.1 \%$ 溶液を $50^{\circ} \mathrm{C}$ から $20^{\circ} \mathrm{C}$ まで俆冷し, 一週間 $20^{\circ} \mathrm{C}$ に保っ て結晶を析出せしめた。この析出物を, ガラスフィルターでロ過 し，マット状にする。得られたマットの配向のようすをX線回折 図で検討した結果，主鎖はマット面に平行に横たわっていること がわかった。この点についての詳細は第 2 報に捛いて述べる。こ の時の結晶型は Type II である。溶媒蒸発法によるフィルムは キシレンを溶媒として $50^{\circ} \mathrm{C}$ で作製した。結晶は Type II であ る。各結晶型の代表的作成法を以下に示す。

Type II ：（1） 溶融状態より $66 \sim 30^{\circ} \mathrm{C}$ の温度範囲で等温結 晶化させる。（2）結晶化温度 $20^{\circ} \mathrm{C}$ 以上の温度で溶液から結晶 化させる。（3）溶融状態より念冷した後， $60 \sim 70^{\circ} \mathrm{C}$ の温度範 囲で熱処理する。

Type I：（1） 溶融状態より急冷後, $42 \sim 55^{\circ} \mathrm{C}$ の温度範囲で 熱処理する。（2） $20^{\circ} \mathrm{C}$ 以下の結晶化温度で溶液から結晶化さ せる。ただし, 溶液から Type II, Type I を結晶化させる際の 溶媒は，テトラヒドロフラン，キシレンーメタノール混合溶媒， テトラリン, ベンゼンーメタノール混合溶媒を用いた。

pof : 溶融状態より $0^{\circ} \mathrm{C}$ 以下に急冷する。

$2 \cdot 2$ 測 定

融点, 結晶転移温度, 結晶転移機構確認のため DTA 測定を行 なった。比容-温度曲線はディラトメトリー法によった。加熱速 度は $0.5^{\circ} \mathrm{C} /$ 分である。転移機構確認および結晶型の確認に X 線測 定を主として行なった。動的粘弾性測定には東洋測器製 Vibron DDV-II 型を用い, 测定周波数は主として $110 \mathrm{~Hz}$, 昇温速度 $1^{\circ} \mathrm{C}$ /分である。

\section{3 結果および考察}

\section{$3 \cdot 1$ 粘弾性}

図 1 に種々の処理を加えた試料の引張り貯蔵弾性率 $\left(E^{\prime}\right)$, 損 失弾性率 $\left(E^{\prime \prime}\right)$ の温度依存性を示した。この図より全体の形と しては PE に非常によく似ていることがわかる。 $E^{\prime \prime}$-温度曲線に

4) K. J. Clark, A. Turner-Jones, D. J. H. Sandiford, Chem. and Ind., 2010 (1962). 
おいて $-145^{\circ} \mathrm{C}$ 付近, $-40^{\circ} \mathrm{C} \sim 30^{\circ} \mathrm{C}$ 付近に吸収が存在する。特 に $-40 \sim 30^{\circ} \mathrm{C}$ は非常に幅広な吸収であり, これは, 多くの吸収 機構が混在しているためでもる。 $-145^{\circ} \mathrm{C}$ 付近の吸收は $\mathrm{PE} の$ $-120^{\circ} \mathrm{C}$ 付近の低温副分散 $\left(\beta_{\mathrm{a}}\right)$ の吸収機構と同一の運動機構, すなわち，PE の場合の主鎖の代りに，POD の場合，側鎖自身 が局所的ねじれ運動を行ならためによるものと考えられる。詳し くは第 5 報で報告する。 $-40 \sim 30^{\circ} \mathrm{C}$ 付近の吸収を詳しく検討す るため, 試料に種々の処理をほどこし粘弾性測定を行なった。結 果を図 2 に示した。ただしこの図は比較のため各試料の $E^{\prime \prime}$ 曲 線を縦軸にそって移動させてある。この図より少なくとも吸収ピ 一クが 4 個存在することがわかる。この 4 個を高温側より $\alpha_{\mathrm{c}}{ }^{\prime}$, $\alpha_{\mathrm{c}}{ }^{\prime \prime}, \alpha_{\mathrm{a}}{ }^{\prime}, \alpha_{\mathrm{a}}{ }^{\prime \prime}$ と名付情る。 $\alpha_{\mathrm{c}}{ }^{\prime}, \alpha_{\mathrm{c}}{ }^{\prime \prime}$ は結晶化度を增加させ る処理をすると（例えば図 2 の急冷試料曲線 2 と溶液結晶化物の マット曲線 4 との比較), 出現するか, またはとの強度を増すの で,この吸収は結晶領域内分子鎖の運動に基づくものと考えられ る。Type II 結晶の $\alpha_{\mathrm{c}}{ }^{\prime}$ 吸収の見掛けの活性化エネルギー $\Delta H^{*}$ は, $E^{\prime \prime}$ の極大值の周波数 $f_{\mathrm{m}}$ の温度依存性より $\operatorname{Rd} \ln \left(1 / f_{\mathrm{m}}\right) /$

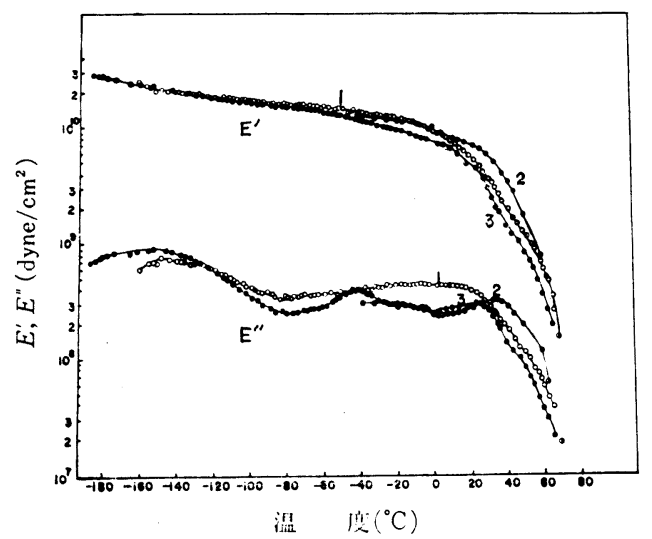

図 1 フイソタクチックポリオクタデセン-1 の引張り 貯蔵弾性率 $\left(E^{\prime}\right)$, 損失弾性率 $\left(E^{\prime \prime}\right)$ の温度特性

曲線 （1）塊状結晶化物，（2）溶液結晶化物，（3）溶媒蒸発法下 より調製したフィルム＼cjkstart陚料調慗条件は本文記載.

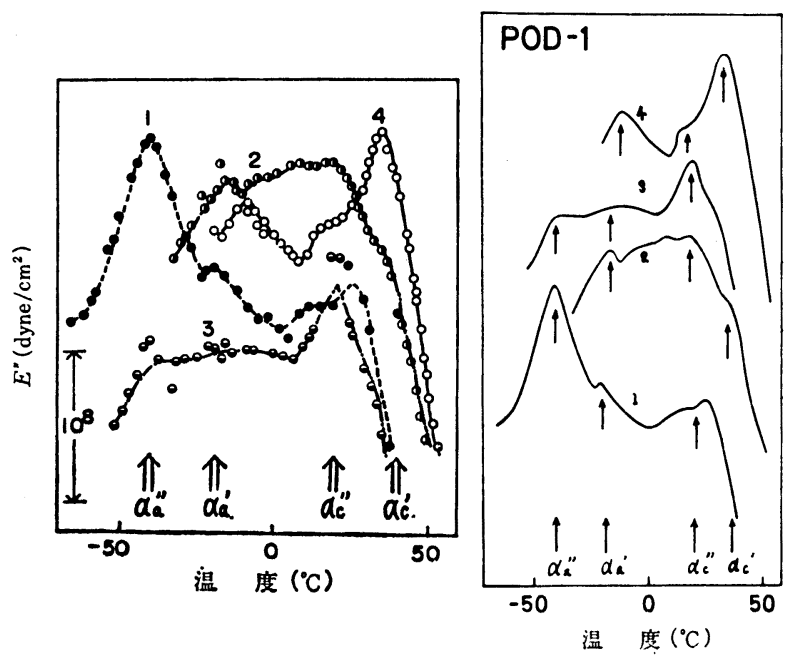

図 2 種々の処理をした POD 試料の $E^{\prime \prime}$ 温度特性 各曲線は緃軸に適当量移動している

曲線 $1:$ 溶媒蒸発法により成膜, $2:$ 急冷試料

$3: 45^{\circ}$ C で 3 倍延伸, $4:$ 溶液より析出した結晶のマット 試料調製方法の群細け本文参咱。 $\mathrm{d}(1 / T)$ の関係から評価すると（図省略)，100 kcal $/ \mathrm{mol}$ 以上で ある。 $\alpha_{\mathrm{c}}{ }^{\prime \prime}$ 吸収のそれは Type II 結晶の場合が $76 \mathrm{kcal} / \mathrm{mol}$, Type I 結晶の量合では $60 \mathrm{kcal} / \mathrm{mol}$ であった。 $\alpha_{\mathrm{a}}{ }^{\prime}, \alpha_{\mathrm{a}}{ }^{\prime \prime}$ 吸収 は結晶化度を減少させ(図 2 の曲線 2 ), 岕るい腫定形領域を分 離せしめる処理（図 2 曲線 1) によって現われることより，この 吸収は無定形領域内分子鎖の運動に苝づくものである。 $\alpha_{\mathrm{a}}{ }^{\prime \prime}$ 吸 収の見掛けの活性化エネルギーは約 $39 \mathrm{kcal} / \mathrm{mol}$ である。続報で 詳しく検討するよらに $\alpha_{\mathrm{a}}{ }^{\prime}$ は主鎖を含むかなり大きな運動単位 の動きによるものであり， $\alpha_{\mathrm{a}}{ }^{\prime \prime}$ 吸収は側鎖自身のミクロブラウ ン運動の生起によるものと考えられる。 $\alpha_{\mathrm{a}}^{\prime \prime}$ は $\mathrm{PE}$ の場合の $\alpha_{\mathrm{a}}$ 吸収 $\left(-25^{\circ} \mathrm{C}\right.$ 付近の吸収) と同様な分子運動によるものである が， $\alpha_{\mathrm{a}}{ }^{\prime}$ に対応する吸収はPE にはみられないことは，第 5 報に おいて側鎖の長さを系統的に変光た場合の結果から結論される。 $\alpha_{\mathrm{a}}{ }^{\prime}$ が pof を多く含む試料に強く出るので， $\alpha_{\mathrm{a}}{ }^{\prime}$ 吸収は pof 独 得の不完全結晶部分の分子鎖による運動に伴なら吸収とも考えら れる。しかしこの領域の分子鎖の運動ならば，PE の組織中にも 同様な状態があれば現われてもよいはずであるが，現在までその 例はない。それ故 $\alpha_{\mathrm{a}}{ }^{\prime}$ 吸収は POD の長い側鎖が規則的に主鎖 に連らなっているという, 化学構造の特徽によるものと考えられ る。すなわち $\alpha_{a}{ }^{\prime \prime}$ 吸収温度からすでに激しくなった側鎖の熱運 動の結果として，それが結合した主鎖をも含む長距離にわたる熱 運動が起こったものと考光られる。さらに $\alpha_{\mathrm{a}}{ }^{\prime}$ が pof に起因す るのでないことは, pof がほとえどない Type II, Type I 結晶 にも $\alpha_{\mathrm{a}}{ }^{\prime}$ はかなり大きく存在すること，および第 2 報に報告す る結晶性が良好で pof を含まない単結晶マット試料では $\alpha_{\mathrm{a}}{ }^{\prime}$ は ほとんどなくなり，その硝酸処理によりさらにその強度が低下す るから明らかである。 $\alpha_{\mathrm{a}}{ }^{\prime}$ 吸収に寄与方る運動は少なくともいわ ゆる完全無秩序の無定形部分, または分子銷には結晶的なコンホ メーションがみられるにせよ, 結晶的な性格を持たない非結晶領 域の運動と考えざるを得ない。pof はこれらの領域に比べて規則 性が高く, 後でディラトメトリー, DTA サーモグラムにより示

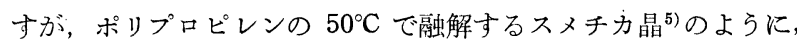
$40^{\circ} \mathrm{C}$ 付近で融解するものであり, 主分散 $\alpha_{\mathrm{a}}{ }^{\prime}$ の原因とは考兄な い。それ故著者等は， $\alpha_{\mathrm{a}}{ }^{\prime}$ 吸収としてポリプロピレン (PP) やポ リブテン-1 (PB-1) の $\alpha_{\mathrm{a}}$ 吸収と同㥞の機槛に近い主鎖の分子 運動（主鎖のミクロブラウン運䡃に近い䡃き）によるもので，そ のさい主鎖の周りの側鎖をも含んだ連䡃によるものと考兄る。た だしその運動単位は PP，PB-1 にお打るそれより相当に広範囲 にわたると考劣てよい。 $\alpha_{\mathrm{a}}{ }^{\prime}$ の吸収機構に刘するこの考党の正当 性は第 5 報でさらに検討する。

各結晶型の損失正接 $(\tan \delta)$-温度曲線を図 3 に示した。曲線 1 および 2 は Type II 結晶, 曲線 3,4 はとれぞれ Type I 結晶 および pof である。この図で示した温庋域にみられる $\tan \delta$ の 值は, その温度域から考えて (Type II の融点 $75^{\circ} \mathrm{C}$, Type I の 融点 $70^{\circ} \mathrm{C}$ ), 結晶領域内分子鎖の運動によるものと考えられる。 この図より明らかなように, Type II 結晶の方が Type I 結晶 に比べて $\tan \delta$ は高温側へ移動する。多なわち Type I 結晶の 分子鎖は Type II 結晶の分子鎖より低温から動き得ることがわ かる。また pof では $45^{\circ} \mathrm{C}$ 付近より急激な $\tan \delta$ の上昇が文ら れるが, これは 3.2 節で述べるように pof なる準結晶相の融解 に伴う分子運動によるものである。

5）南 俊輔, 田上順子, 高柳素夫, 工化, 68, 90 (1965). 


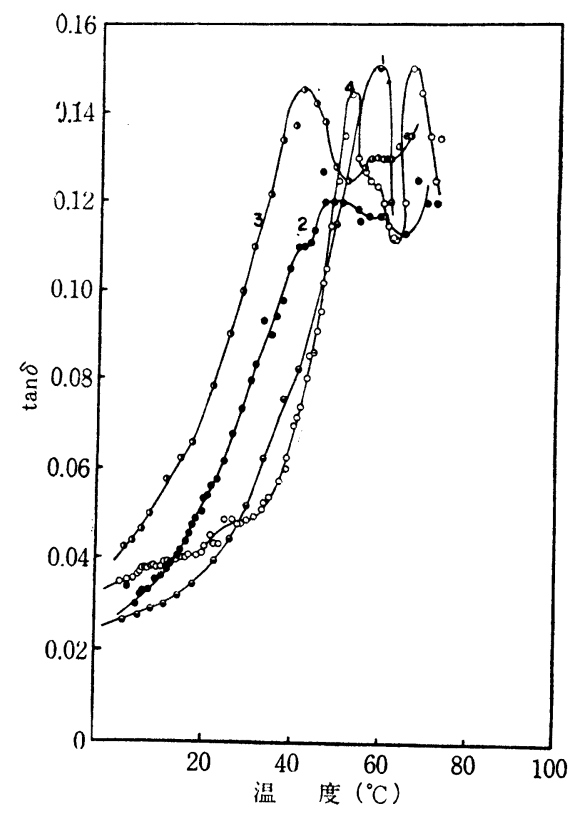

図 3 Type I, II, pof 結晶型 POD の $\tan \delta$ 温度特性

曲 線 $1:$ 溶夜結晶化物 (Type II 結晶)

$2: 69^{\circ} \mathrm{C}$ 熱处理物 (Type II 結晶)

$3: 47^{\circ} \mathrm{C}$ 熱処理物 (Type I 結晶)

$4:$ 融解物索 $-76^{\circ} \mathrm{C}$ へ急冾したるの（pof）

\section{$3 \cdot 2$ 結晶転移現象}

3·2・1 Type II, Type I および pof の融解 図 4, 困 5 に それぞれ各結晶の比容一温原曲線およびDTA曲線を示した。 Type II, Type I, pof の融点はそれぞれ $75^{\circ} \mathrm{C}, 70^{\circ} \mathrm{C}, 38^{\circ} \mathrm{C} て ゙$ ある。ただし融点として DTA のピーク位置をとる。図4 亿おけ る pof の曲線（曲線 3 ）をみると融解に基づく急激な体膨脹を 経て $42^{\circ} \mathrm{C}$ で融解, ひきつづいて急激な体積収縮がみられる。こ の収縮は pof から他の結晶型への転移に伴なら体積収縮である。 Type I 結晶の曲線（曲線 2 ）は $55^{\circ} \mathrm{C}$ にわずかに体積の異常膨 脹攵見いだされる。Type II 結晶の曲線(曲線 1)は $75^{\circ} \mathrm{C}$ に融点 を与えるのみである。図5 の DTA 曲線では, pof（曲線 3) は

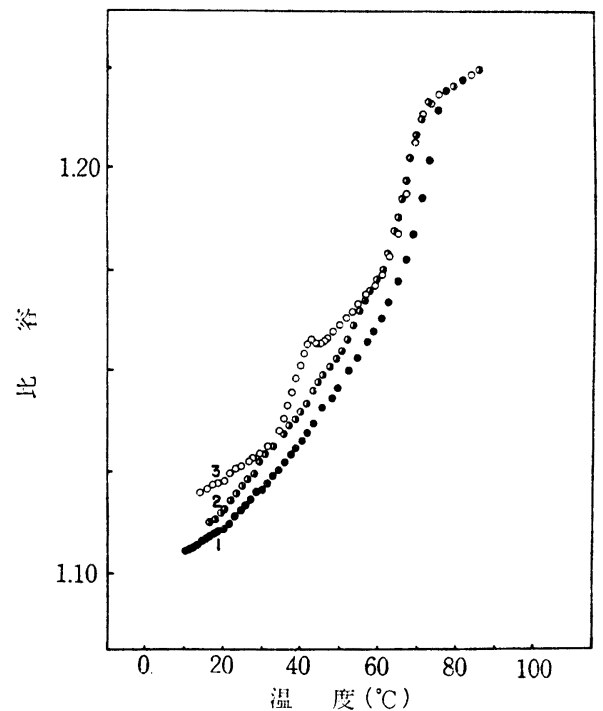

図 4 Type I, II, pof 結晶型 POD の比容-温度特性

$$
\begin{aligned}
& \text { 曲線 } 1: 69^{\circ} \mathrm{C} \text { での熱処理物 (Type II 結晶) } \\
& 2: 47^{\circ} \mathrm{C} \text { での熱処理物 (Type I 結晶) } \\
& 3: \text { 溶融物を }-76^{\circ} \mathrm{C} \text { に急冷 (pof) }
\end{aligned}
$$

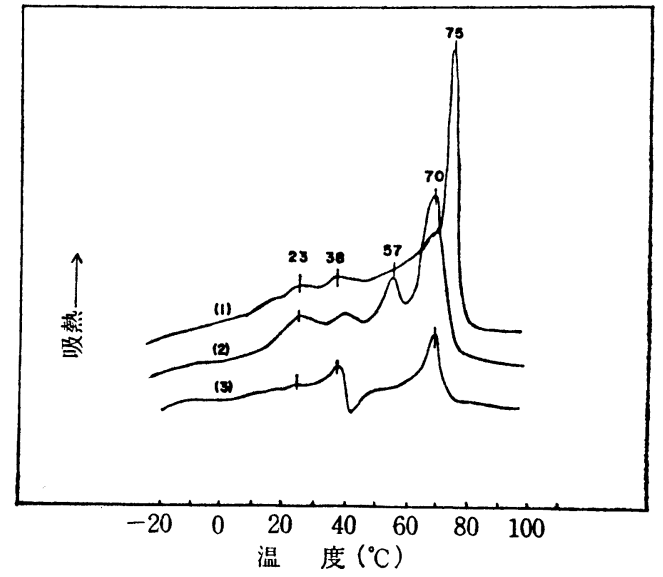

図 5 各結晶型 POD の DTA 曲線

曲 線 $1: 69^{\circ} \mathrm{C}$ 热処理物 (Type II 絬脂)

$2: 47^{\circ} \mathrm{C}$ 然处理物 (Type I 絬品)

$3:$ 深融物を $-76^{\circ} \mathrm{C}$ 亿急冷 (pof)

$38^{\circ} \mathrm{C}$ に pof の融解に基づく吸熱ピーク，さらに結晶化に基づく 発熱ピークが $42^{\circ} \mathrm{C}$ 付近に観察される。これは図 4 の比容-温度 曲線の結果とよく一致する。Type I (曲線 2) は $23^{\circ} \mathrm{C}, 38^{\circ} \mathrm{C}$, $57^{\circ} \mathrm{C} ， 70^{\circ} \mathrm{C}$ に吸熱ピークがみられる。 $38^{\circ} \mathrm{C}$ のピークは pof の 混在によるもの, $70^{\circ} \mathrm{C}$ は Type I の mp. $23^{\circ} \mathrm{C}$ のピークは Type II（曲楾 3）でも観察されるが，何によるものか明らかでない。 $57^{\circ} \mathrm{C}$ のピークは Type I のみにみられ, これは比容-温度曲線に おける $55^{\circ} \mathrm{C}$ の体積異常に対応するものであろう。

$3 \cdot 2 \cdot 2$ pof より他の結晶型への転移 pof より他の型への $40^{\circ} \mathrm{C}$ 付近の転移の機構を考えてみる。四 6 に pof についての $\tan \delta$ 温度曲線, DTA, 比容-温度曲線の結果をまとめて示した。この 図より pof は $40^{\circ} \mathrm{C}$ で融解し，ただちに結晶化して他の型へ移る ことがわかる。X線測定結果より Type I へ移っていることが確 認された。すでに述べたよらに pof より Type I への転移は固 体-液体一固体転移であり，またその温度位置の加熱速度依存性は 少なかった。

Type I はX線測定によると $62 \sim 65^{\circ} \mathrm{C}$ 付近より徐々に Type II へ転移していく。延伸処理は Type II への転移温度をさらに 低温側に移行させる。両結晶間には明確な転移点は存在しない。 非常にゆっくりとした加熱速度では，見掛上転移点を示さず徐々 に Type I から Type II に変化する。これらの転移機構をさら

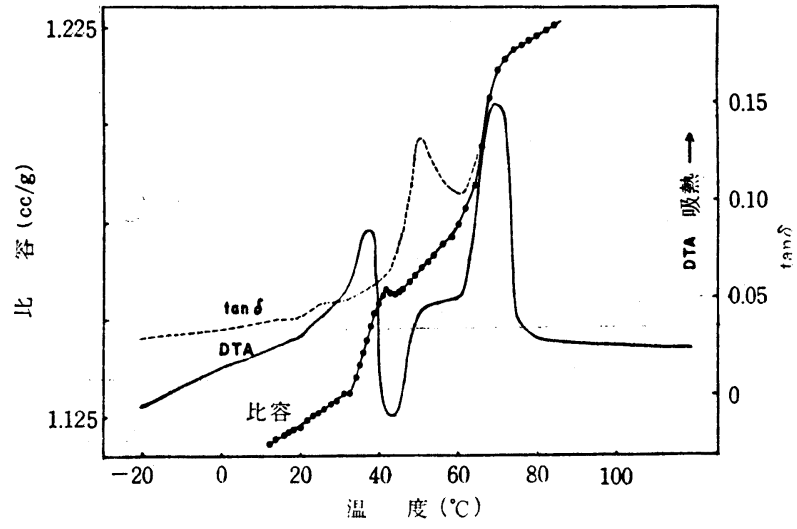

図 6 POD の不完全結晶 pof の $\tan \delta$, 比容-温度特性とDTA

困中，破線は $\tan \delta$-温度特性，实線は DTA 曲線，黑丸は比容一温度曲線 
に詳しくしるためディラトメトリー，X線測定を行なった。

ディラトメトリーは以下のよらな実験方法で行なった。まず, -76 $\mathrm{C}$ に急冷した武料をディラトメーターに允てんし，42.0土 $0.1^{\circ} \mathrm{C}$ に設定した bath 中に急激に入れて，その時の体積の時間 的变化を測定する。 50 分間測定後直ちに $-76^{\circ} \mathrm{C}$ に急冷し，次 に $50^{\circ} \mathrm{C}$ に設定した bath 中に急激に入れ体積一時間曲線を求め, 50 分問測定後直ちに $-76^{\circ} \mathrm{C}$ に急冷する。さらに高温に設定し た bath 中にこのディラトメーターを入れ，体積一時間曲線を求 める。以上の操作をくり返し $72^{\circ} \mathrm{C}$ まで測定した後, その試料を 急冷し, 今度は $0.5^{\circ} \mathrm{C} / \mathrm{min}$ の年温速度で体積一温度曲線を測定寸 る。結果を図 7 , 図 8 に示した。図 7 中 $45.6^{\circ} \mathrm{C}$ の曲線は $50.0^{\circ} \mathrm{C}$ での測定後の試料についてのものであり，これはほとんど休積の 時間変化が見られないことを確かめるために，測定したものであ る。すなわち一度高温で熱処理したものではより低温の温度では 体積一時間曲線で大きな变化はみられない。図中黒丸の曲線,すな

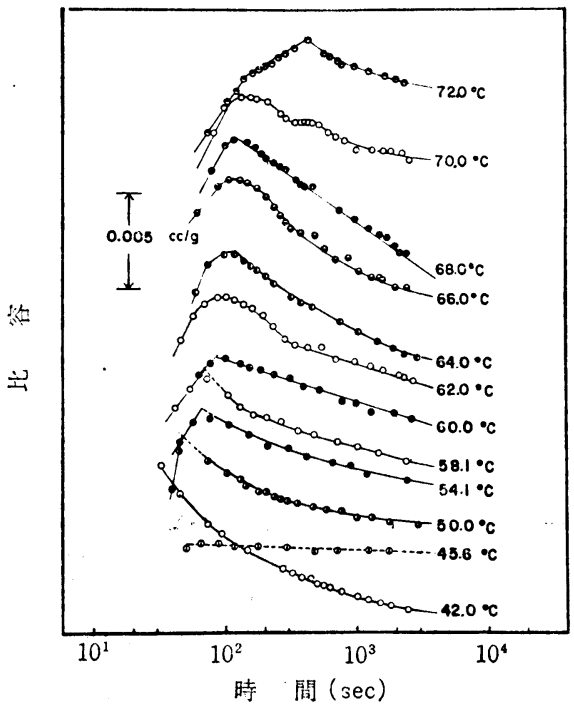

因 7 急冷試料（pof）の各種温度での比容-時間曲線 各曲線は綐軸にそって適当量平行移動している。

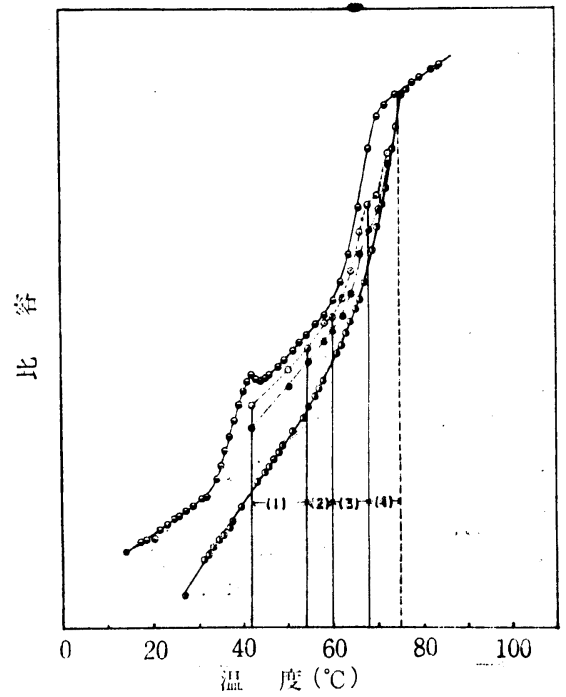

図 8 急冷試料战よび図 7 の試料の比容-温度曲線

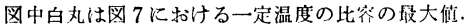

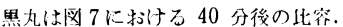

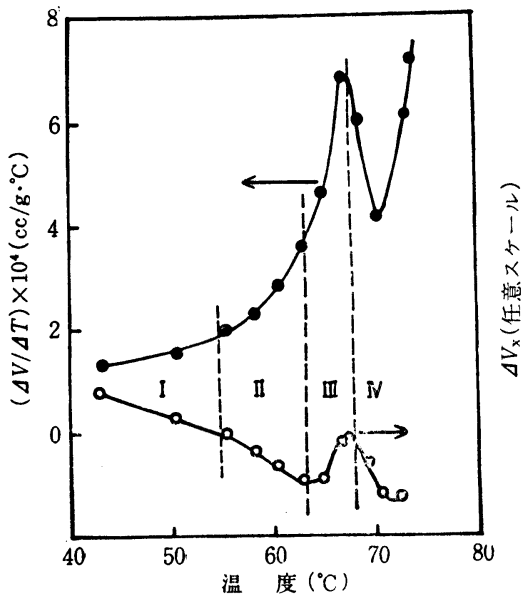

図 9 熱処理による結晶化度の增加 $\left(-\Delta v_{x}\right)$ と階段 状温度变化に伴なら体積变化率 $(\Delta v / \Delta T)$

わち $54.1^{\circ} \mathrm{C}, 60.0^{\circ} \mathrm{C}, 68.0^{\circ} \mathrm{C}$ を境にして図の曲線群はその形状 からみて近似的に四つの領域に分けることができる。この関倸は 図8, 図 9 でさらに明らかに示される。図 8 は溶融状態より -76 ${ }^{\circ} \mathrm{C}$ に急冷した試料 (図 7 の原試料に相当) の比容-温店曲線（下半 黑丸), および図 7 の $72^{\circ} \mathrm{C}$ の比容-時間曲線测定終了後の試料を 一定昇温速度で測定した比容-温度曲線（右半黒丸），および図 7 における各設定温度での比容の最高值(白丸)，および40 分にお ける比容の值（黒丸）を設定温应に対してプロットした曲線の 4 種の曲線を同時に示したものである。図 7 の黑丸の設定温度を図 8 では縦軸に平行な直線で示した。図 8 における黒丸の点の結晶 化屡の目安として黒丸の比容值と熱処理陚料（右半黑丸）の比容 值との差 $\left(\Delta v_{x}\right)$ をとった。この扂 $\left(\Delta v_{x}\right)$ が小さいほど高い結晶 性をもつ。また階段状に温度変化を与えた时の見掛上の膨脹係数 を求めた。これら結晶化度の相対值の目安を与える $\Delta v_{x}$ （白丸） および見掛上の膨脹係数 $(\Delta v / \Delta T)$ を温度に対してブロットした 結果（黒丸）を図 9 に示した。ただしここで見掛けの膨脹係数は 次のようにして定義したものである。すなおち, 図 10 のよらに $-76^{\circ} \mathrm{C}$ より $T_{1}$ なる温度に試料を設定し 40 分後の比容を $v_{1}$ と する。次に設定温度 $T_{2}$ における比容の最大俻を $v_{2}$ とすると見 掛けの膨脹係数は $\left(v_{2}-v_{1}\right) /\left(T_{2}-T_{1}\right)$ で定義される。 $\left(v_{2}-v_{1}\right)$ は 温度変化 $\left(T_{2}-T_{1}\right)$ による粠造变化なしに体膨脤と, $T_{1}$ から $T_{2}$ へ温度変化したために生じる構造变化（結晶化や融解など）にも とづく体膨脹を同時に含んだものである。図 9 は 4 つの領域にわ

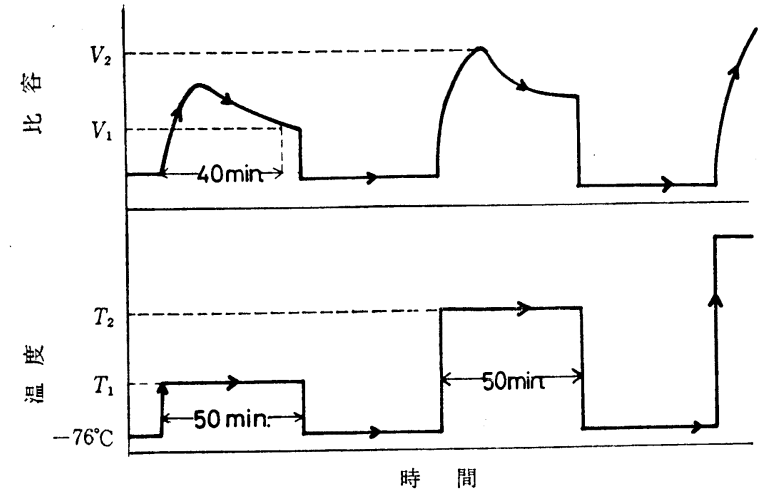

図 10 図 7 の実験法および図 9 の $\Delta v_{x}, \Delta v / \Delta T$ の定義を示す模型図 
けることができ，この境界の温度は図 8 の境界の温度とほぼ一致する。これら 4 つの領域は図 9 の絬果より次の特徽をも つことがわかる。領域 I $\left(42 \sim 55^{\circ} \mathrm{C}\right)$ で は階段状温度变化による体膨脹は少なく， しかも熱処理による絬品化度の上界も少 ない。領域 II $\left(55 \sim 63^{\circ} \mathrm{C}\right)$ では階段状温 度変化による体膨脹はかなり大きく, 同 表 1 熱処理過程における各種 X線反射の試料内での強度順位の变化

\begin{tabular}{|c|c|c|c|c|c|c|c|c|c|}
\hline 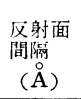 & $\begin{array}{l}\text { 融解物を } \\
-76^{\circ} \mathrm{C} に \\
\text { 急喻 } \\
\quad \equiv A\end{array}$ & $\begin{array}{c}*(\mathrm{~A}) \\
\left(42^{\circ} \mathrm{C}\right) \\
(3 \mathrm{~min}) \\
\equiv B\end{array}$ & $\begin{array}{l}*(\mathrm{~A}) \\
\left(42^{\circ} \mathrm{C}\right) \\
(40 \mathrm{~min}) \\
\equiv C)\end{array}$ & $\begin{array}{l}{ }^{*}(\mathbf{A}) \\
\left(60^{\circ} \mathrm{C}\right) \\
(3 \mathrm{~min})\end{array}$ & $\begin{array}{l}*(\mathrm{~A}) \\
\left(55^{\circ} \mathrm{C}\right) \\
(40 \mathrm{~min})\end{array}$ & $\begin{array}{l}*(\mathrm{C}) \\
\left(55^{\circ} \mathrm{C}\right) \\
(40 \mathrm{~min})\end{array}$ & $\begin{array}{l}{ }^{*}(\mathrm{~B}) \\
\left(60^{\circ} \mathrm{C}\right) \\
(3 \mathrm{~min})\end{array}$ & $\begin{array}{l}*(\mathrm{~A}) \\
\left(47^{\circ} \mathrm{C}\right) \\
(3 \mathrm{~min}) \\
\equiv D\end{array}$ & $\begin{array}{l}*(\mathrm{D}) \\
\left(56^{\circ} \mathrm{C}\right) \\
(10 \mathrm{~min})\end{array}$ \\
\hline 4.22 & 1 & 1 & 1 & 1 & 2 & 3 & 3 & 3 & 3 \\
\hline 4.78 & - & 2 & 2 & 2 & 1 & 2 & 2 & 2 & 2 \\
\hline 16 & - & - & - & - & 2 & 4 & 4 & 3 & 3 \\
\hline 48 & - & - & - & - & 1 & 1 & 1 & 1 & 1 \\
\hline
\end{tabular}

* 最上段の（）は試料名，中段は熱处理温度，下段は熱処理時間を意味する. 例えばB試料は $\mathrm{A}$ 試料を $42^{\circ} \mathrm{C} て ゙ 3$ 分間熱処理したものである。また最終列の試料はD試料（これは $\mathrm{A}$ 試料を $47^{\circ} \mathrm{C} て ゙ 3$ 日間熱処理したもの)を $56^{\circ} \mathrm{C}$ で 10 分間熱处理したものに相当する。
時に熱処理による結晶化度の増加は大きい。領域 III $\quad\left(63 \sim 68^{\circ} \mathrm{C}\right)$ では階段状温度变化に伴なう体膨脹は大きく熱処理による結晶化 度の増加は汪とんどみられない。領域 N $\left(68 \sim 72^{\circ} \mathrm{C}\right)$ では階段状 温度変化に伴なら体膨脹は大きく, 熱処理による結晶化度の増加 がみられる。

領域 I, II は pof から Type I への転移温度域であり, この 温度域が二つの領域に分れるのは, この転移機構が主として二つ の過程から成立しているためと期待される。

表 1 に，X線測定結果より得られた反射強度の順位を示した。 $4.22 \AA$ は pof の反射で, $4.78 \AA$ は Type I 結晶の側鎖からの 反射であり，16 16 , $48 \AA$ Type I 結晶の主鎖からの反射であ る1)。この表より明らかなように $42^{\circ} \mathrm{C}$ ではまず $4.78 \AA$ の反射 が強くなる。このことは $42^{\circ} \mathrm{C}$ で pof が融解後まず側鎖のみが Type I 結晶の充てん状態になることを意味する。続いて 55〜60 ${ }^{\circ} \mathrm{C}$ の範囲で主として主鎖の Type I 結晶への規則性の増加が起 こっていることが $16 \AA$ および $48 \AA$ の反射強度の增加よりわか る。図 9 および表 1 の結果より領域 1 ではまず側鎖の及が急激に Type I の結晶をつくろらとするが，主鎖はまだ Type I の規則

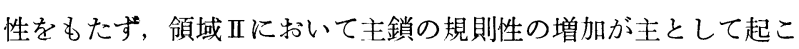
る。しかし $47^{\circ} \mathrm{C}$ で3 日間熱処理すると表 1 で明らかなように, 主鎖からの反射も生じるが, $60^{\circ} \mathrm{C}, 3$ 分間の短時間熱処理のみで は主鎖からの反射は見いだせない。それ故，領域 I，II の区別は pof より Type I 結晶への転移のさい, 側鎖と主鎖との運動性の 差から生じたものである。前者の方が後者よりより低い温度で, またより短い時間内で規則性をもつ。

3·2·3 Type I より Type II への転移 領域 III Type I 結晶の融解温度域にあたることを考慮すると, 領域正で急激な体 膨脹が起こること, および熱処理による結晶化度の増加が少ない 理由が理解できる。すなわち Type I 結晶の融解による体膨脹ま たは Type II 結晶への転移の際の一時的な体膨脹が領域吕で起 こり, この融解または転移により, 一時的な結晶化度の減少がみ られたのである。この温度範囲では Type I 結晶の融解後, Type II 結晶への再結晶かまたは Type I 結晶から Type II 結 晶への固体間での転移が起こっている。ディラトメトリーの結果 は一見前者の機溝を支持するように思われるが，Type I の mp より低い $60^{\circ} \mathrm{C}$ でも長時間処理により Type II へ移る。一方 Type I から Type II への転移は実際にX線測定結果より確かめられ, この領域では Type I と Type II 結晶とが共存していることが わかった。これらの結果より, 領域III, N は次のように理解され る。すなわち領域III，N は主として Type I 結晶より Type II 結晶へ転移する温度範囲に当たる。その転移機構はX線测定結果 によると pof から Type I 結晶への場合と異なり, 主鎖, 側鎖 ともに Type II 結晶の配位および充てん状態へとほぼ同時に転 移する。領域 III, N の違いは Type I 結晶またはその融解物から
Type II 結晶への転移速度と Type I 結晶の融解速度との競争 によって，見掛上定まったものと考えられる。Type I 結晶から Type II 結晶への転移が比容や DTA 測定に顕著に出てこない のは, 主としてその転移速度が加熱速度に比して遅いためと考え られる。

次に, この二つの転移が熱力学的可逆性のある転移かどうか知 るため, Type II 結晶を作り以下の奉験を行なったっこの結晶型 の久を有する陚料を $70 〜 58^{\circ} \mathrm{C}$ まで $2^{\circ} \mathrm{C} / \mathrm{day}$ の速度で降温し， $58^{\circ} \mathrm{C}$ で 1 日效処理しさらに $52^{\circ} \mathrm{C}$ まで $2^{\circ} \mathrm{C} / \mathrm{min}$ で降温し, $52^{\circ} \mathrm{C}$ で3 日間熱処理した。これら各過程でX線写真をとり, その変化 の様子をみたが, Type II 結晶のままで变化はみられなかった。 すなわち Type II 結晶から Type I 結晶への転移は $20 \sim 75^{\circ} \mathrm{C}$ の範囲では見いだせなかった。これより Type II 結晶が 20〜75 ${ }^{\circ} \mathrm{C}$ の温度域で最も熱力学的に安定な結晶であることがわかり,

Type II 結晶から Type I 結晶, または Type II 結晶から pof への転移はない。同時に Type I 結晶から pof への転移も観察 されなかった。以上の転移の関係をまとめて示したのが図 11 で ある。ただしこの図において quen. は液体状態より $-76^{\circ} \mathrm{C}$, ま

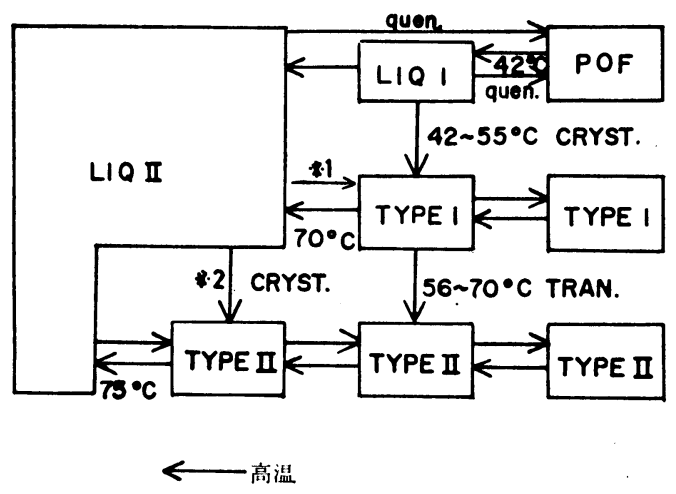

図 11 結晶型間の転移を示すダイアグラム

四中 *1は肴薄溶液より $10^{\circ} \mathrm{C}$ 以下で等温結晶化させることを意味 する. ${ }^{*} 2$ は $20^{\circ} \mathrm{C}$ 以上の温度での溶融物の等温結晶化を意味する。

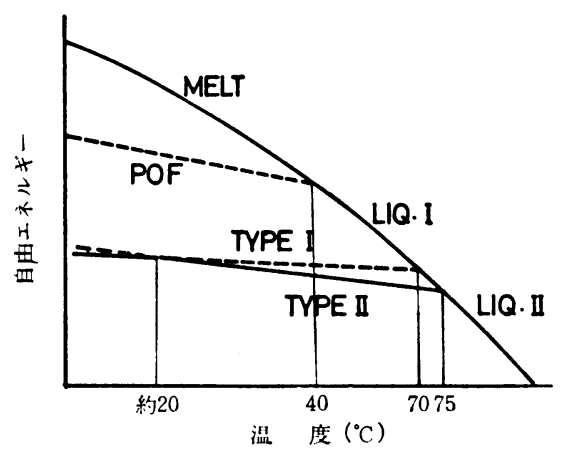

図 12 各種結晶型の自由エネルギー温度特性の模式図 図中実值線はその温度における安定結晶を示す。 
には $-192^{\circ} \mathrm{C}$ へ急冷することを意味し, cryst. は等温結晶化を 意味する。Trans.は絬唱一絬晶間の転移で固体-液体一固体転移 および固体一固体転移の区別はしていない。また liq. I と liq. II の区別は前者が pof を融解したさいできる不安定な液体状態を 示し, 後者は Type I 結晶拉よび Type II 結晶の融解によって 生じる液体状態を意味している。 liq. II から Type I 結晶への 等温結晶化は, ポリマー自体の融解状態からでは不可能であった が，溶液から析出させる結晶化（約 $10^{\circ} \mathrm{C}$ 以下）では Type I 結 晶のみを作ることができる。結局 Type I 結晶および pof は 20 $\sim 75^{\circ} \mathrm{C}$ の温度範用で熱力学的には準安定状態であり, 従って子
想される自由エネルギーと温度との関係は四 12 で与えられる。 この図に打いて破線は不安定楧造の自由エネルギー曲線を示し， 太い実線は液体状態の自由エネルギー曲線を示したものである。 各 Type に対応する線が融点以外では交叉しない点が注目すべ き点である。ただし $20^{\circ} \mathrm{C}$ 以下では Type I 曲線と Type II 曲 線とは交攴する可能性が強い。なぜならば $20^{\circ} \mathrm{C}$ 以下で溶液より 析出せしめた結晶は Type I, II 結晶の混合となり， $5^{\circ} \mathrm{C}$ 以下で は Type I 結晶のみとなるので $20^{\circ} \mathrm{C}$ 以下の低温では Type I 結 晶の方が熱力学的に安定な構造と考えられるからである。

\title{
アイソタチックポリオクタデセン-1 単結晶の構造と粘弾性 ${ }^{* 1,2}$
}

(昭 和 45 年 1 月 31 日 受 理)

\author{
真 鍋 征 - ${ }^{* 3}$ ・南 庄 治*4 高 柳 素 夫*5
}

アイソタクチックポリオクタデセン-1（略記号 POD）の単結晶を次の 2 方法によって得ることができた。（1） $0.01 \%$ テトラ リン溶液を温度範囲 $0 \sim 15^{\circ} \mathrm{C}$ に拈ける一定温度で等温結晶化させる。（2） $0.01 \%$ のメタノール/キシレン混合溶液（溶媒混合比 $1: 4 ＼mathrm{~ よ り ~} 1^{\circ} \mathrm{C} /$ 時間の冷却速度で $55^{\circ} \mathrm{C}$ より $20^{\circ} \mathrm{C}$ まで徐冷する。

方法（2）で得られた結晶はTurner-Jones の命名による Type II 結晶と格子定数がほぼ一致し，その単結晶では側鎖が板状結 晶の板面に垂直に立っている。しかもこの単結晶の層厚は単分子層または二分子層よりなっていることがわかった。方法（1）で 得られた結晶も電子線回折図は方法（2）で得られた単結晶と一致するが，Type III なる六方晶系の結晶も混在していた。これ はTurner-Jones により明確な結晶形態をとるものとは考えられていなかった。方法（1）で得られた単結晶マットの粘弾性挙 動を調べた。 $\alpha_{\mathrm{c}}{ }^{\prime \prime}$ 吸収が大きく $\alpha_{\mathrm{a}}{ }^{\prime}, \alpha_{\mathrm{a}}{ }^{\prime \prime}$ 吸収もわずかに見いだされた。 $\alpha_{\mathrm{a}}{ }^{\prime}, \alpha_{\mathrm{a}}{ }^{\prime \prime}$ 吸収の生じる原因を，単結晶側面にある結 晶に入らない自由な末端鎖の存在によると考之た。熱処理効果と発煙硝酸処理効果を通して, ポリチレン単結晶との相違を検討 し, POD 中の主鎖の影響が粘弾性挙動に顕著に現われることを示した。

\section{1 粕 言}

Turner-Jones ${ }^{1)}$ はアイソタクチックポリオクタデセン-1(POD) の Type II 結晶構造について考察した。また第 1 報によって 20 ${ }^{\circ} \mathrm{C}$ 以上の溶液より成長させた結晶が Type II 結晶になること, およびその粘弾性挙動を示した。それによると，この試料では， $-50^{\circ} \mathrm{C}$ 以上の温度域において, 結晶内分子鎖の運動による吸収 が 2 個，無定形領域内分子鎖の運動による吸収が少なくとも 2 個 観察されることを明らかにした。もし POD の単結晶が得られる ならば以下のような興味ある問題が提起される。まずこの特異な 化学構造を持つ単結晶の主鎖および側鎖つ充てん状態が問題にな る。現在まで知られている高分子単結晶では主鎖が結晶の板面に 垂直に立っていることが明らかにされているが，POD 単結晶で は側鎖が板面に垂值に立つことが期待される。この単結昆で主鎖 はどのような配向状態で単結晶中に存在するのか，主鎖の折りた

${ }^{*}$ 1 この報文を「分岐のない側鎖をもつポリー $\alpha$-オレフィン系 列の粘弾性と結晶転移現象 (第 2 報)」とする.

*2 前報(第 1 報), 真鍋征一, 高柳素夫, 工化, 73, 1572(1970).

*3 Seiichi MANABE 現在旭化成繊維研究所: 高柣市八丁畷 町.

*4 Shoji MINAMI 現在日本鉱業（株）：倉敷市水島.

*5 Motowo TAKAYANAGI 九州大学工学部応用化学教室 : 福岡市箱崎.

1) A. Turner-Jones, Makromol. Chem., 75, 1 (1964).
たみ構造は存在しているか, 層厚の結晶化温度および熱処理温度 に対する依存性はどうか等がポリエチレン $(\mathrm{PE})$ 単結晶の場合と 比較して興味ある問題となる。

次にこの単結晶の粘弾性挙動に関する問題である。粘弾性挙動 では先に見いだした $\alpha_{\mathrm{c}}{ }^{\prime}, \alpha_{\mathrm{c}}{ }^{\prime \prime} ， \alpha_{\mathrm{a}}{ }^{\prime} ， \alpha_{\mathrm{a}}{ }^{\prime \prime}$ 吸収が単結晶ではど のように変化するのか, それぞれの吸収の機構, 化学構造, 結 晶構造との結びつき, 粘弾性挙動に対する主鎖の影響が問題にな る。 $\alpha_{\mathrm{c}}$ 吸収の挙動は $\mathrm{PE}$ 単結晶の場合と比較することにより多 くの知見を得ることができよう。著者ら ${ }^{2)}$ は $\mathrm{PE}$ 単結晶について $\alpha_{\mathrm{c}}$ 吸收強度およびその温度位置におよぼす層厚の影響について 報告した。そこでは温度位置は層厚によってほぼ確定するが，吸 収強庋は同一層厚でも等温結晶化で得たものか, 熱処理を受けた ものかによってまったく異なる。これを著者等は熱処理による結 晶の乱れによるものとみなしたが, 本試料の単結晶の予想される 構造を考学ると，熱処理により層厚は変化しないことが期待され るので熱処理効果のらち温度の変化の影響の及索独立にとりだす ことが可能であろら。著者等の考えによるならば, 熱処理による 層厚の増加に伴なって欠陥が生じるので, 層厚の变化を伴なわな い熱処理では $\alpha_{\mathrm{c}}$ 吸収強度は变化しないはずであり，当然温度位 置も変化しないはずである。

2) M. Takayanagi, T. Matsuo, J. Macromol. Sci-Phys., B 1 (3), 407 (1967). 